\title{
Pencirian Molekul Glikogen Sintase Kinase-3 dari Eimeria tenella
}

(Molecular Characterisation of Glycogen Synthase Kinase-3 from Eimeria tenella)

\author{
PING-Ping YAO, MOHD FIRdAus RAIH, HASIDAH MOHD SidEK, \\ NOOR EMBI \& KIEW-LIAN WAN*
}

\begin{abstract}
ABSTRAK
Penemuan sasaran dadah antikoksidia baharu merupakan antara usaha yang diperlukan untuk mengawal penyakit koksidiosis ayam yang disebabkan oleh spesies Eimeria. Dalam kajian ini, serpihan yang mengekodkan glikogen sintase kinase-3 (GSK-3) Eimeria tenella putatif telah diamplifikasi daripada cDNA E. tenella. Hasil pemadanan homologi menunjukkan jujukan GSK-3 E. tenella yang terjana mempunyai padanan yang tinggi dengan jujukan GSK-3 organisma lain. Domain terpulihara GSK-3 dan residu yang penting untuk aktiviti GSK-3 juga diramalkan hadir dalam jujukan GSK3 E. tenella. Analisis struktur sekunder serta pemodelan homologi menunjukkan pembahagian struktur protein kepada domain bebenang beta pada hujung $N$ dan domain heliks alfa pada hujung $C$, yang merupakan ciri enzim GSK-3. Kesemua hasil analisis ini menyokong bahawa jujukan yang dikaji mengekodkan protein GSK-3 dalam E. tenella. Walaupun darjah keterpuliharaan adalah tinggi, namun terdapat perbezaan yang bermakna diperhatikan antara GSK-3 E. tenella dan perumahnya. Residu Ser 9 yang dilaporkan penting untuk perencatan aktiviti GSK-3 didapati tidak terpulihara dalam GSK-3 E. tenella. Memandangkan Ser 9 merupakan tapak pemfosfatan bagi GSK-3 $\beta$ dalam haiwan vertebrata, ketiadaan residu ini dalam jujukan GSK-3 E. tenella mencadangkan bahawa pengawalaturan GSK-3 E. tenella melibatkan tapak pemfosfatan dan mekanisme yang berbeza. Tambahan pula, hasil analisis filogenetik menunjukkan bahawa GSK-3 E. tenella mempunyai pertalian yang rapat dengan protein GSK-3 tumbuh-tumbuhan. Analisis superposisi GSK-3 E. tenella dengan GSK-3 $\beta$ Homo sapiens pula menunjukkan bahawa perencat GSK-3 mampu berinteraksi dengan protein GSK-3 E. tenella. Keputusan kajian ini mencadangkan bahawa GSK-3 E. tenella mempunyai potensi untuk diperkembangkan sebagai sasaran dadah antikoksidia.
\end{abstract}

Kata kunci: Koksidiosis; parasit protozoa; sasaran dadah anti-koksidia

\section{ABSTRACT}

The discovery of new anticoccidial drug targets is amongst the necessary efforts needed to control chicken coccidiosis caused by Eimeria species. In this study, the fragment coding for the putative Eimeria tenella glycogen synthase kinase-3 (GSK-3) was amplified from the cDNA of E. tenella. Homology search showed that generated E. tenella GSK-3 sequence has high similarities with GSK-3 sequences from other organisms. The conserved domains of GSK-3 and residues important for the GSK-3 activity were also predicted within the E. tenella GSK-3. Secondary structure analysis and homology modelling predicted that the protein structure is divided into a beta strand domain at the $N$ terminal and an alpha helix domain at terminal $C$, which are characteristics of GSK-3 enzymes. These results supported the E. tenella GSK-3 codes for the GSK-3 protein in E. tenella. Although the degree of conservation is high, significant differences were observed between GSK-3 of E. tenella and its host. The Ser 9 residue reported to be important for the inhibition of the GSK-3 activity was not conserved within the E. tenella GSK-3. Considering that Ser 9 is a phosphorylation site in GSK-3 $\beta$ of vertebrates, the absence of this residue in the E. tenella GSK-3 sequence suggests that the regulation of E. tenella GSK-3 involves a different phosphorylation site and mechanism. Phylogenetic analysis suggests that E. tenella GSK-3 has a closer relationship to plant GSK-3. Superposition analysis between E. tenella GSK-3 and Homo sapiens GSK-3 $\beta$ predicted that E. tenella GSK-3 is able to interact with a GSK-3 inhibitor. Taken together, these results suggested that the E. tenella GSK-3 has the potential to be developed into an anticoccidial drug target.

Keywords: Anti-coccidial drug target; coccidiosis; protozoan parasite

\section{PENGENALAN}

Spesies Eimeria merupakan parasit protozoa yang penting sebagai penyebab penyakit koksidiosis ayam. Serangan parasit ini biasanya dikaitkan dengan keradangan dan pendarahan yang teruk pada usus ayam sehingga boleh menyebabkan kematian. Patologi jangkitan ini disebabkan oleh penyerangan parasit terhadap sel epitelium usus ayam untuk tujuan replikasi aseksual. Antara spesies Eimeria yang menginfeksi ayam, Eimeria tenella dianggap sebagai yang paling penting berdasarkan kepatogenan dan kehadiran dalam ladang. Setiap tahun, penyakit koksidiosis ayam menyebabkan kerugian ekonomi 
global yang dianggarkan melebihi US\$3 bilion (Blake \& Tomley 2014). Pengawalan koksidiosis yang berkesan melibatkan penggunaan vaksin dan kemoterapi. Namun, penghasilan vaksin yang berkualiti adalah sukar dan kos penggunaan vaksin adalah tinggi (Shirley et al. 2005). Lagipun, kaedah penggunaan vaksin adalah rumit dan ini mengurangkan minat para penternak ayam. Penggunaan vaksin hidup virulen juga mampu mencetuskan wabak koksidiosis yang serius disebabkan oleh kevirulenan parasit yang dikekalkan dalam vaksin tersebut (Williams 2002). Oleh yang demikian, penggunaan kemoterapi masih merupakan kaedah yang digemari para penternak ayam. Ini adalah kerana dadah antikoksidia mempunyai keberkesanan yang tinggi dan kos yang rendah berbanding dengan pemvaksinan (Chapman et al. 2010). Namun begitu, penggunaan kemoterapi yang tidak terkawal telah menyebabkan masalah kerintangan dadah (Chapman 1997). Oleh itu, penghasilan dadah antikoksidia yang baharu adalah perlu kerana masalah kerintangan telah dilaporkan untuk semua dadah antikoksidia sedia ada (Allen \& Fetterer 2002).

Glikogen sintase kinase-3 (GSK-3) merupakan sejenis protein kinase serina/treonina. Kajian awal mencadangkan GSK-3 berperanan dalam pengawalaturan metabolisme glikogen sahaja (Embi et al. 1980). Namun demikian, GSK-3 didapati berperanan penting dalam pengawalaturan proses sel seperti pengisyaratan insulin dan transkripsi gen dalam nukleus sel (Frame \& Cohen 2001). Masalah seperti diabetes, kanser dan penyakit neurologi Alzheimer's dikaitkan dengan keralatan dalam pengawalaturan GSK-3 manusia (Ali et al. 2001). Homolog GSK-3 ditemui dalam pelbagai organisma hidup, termasuk dalam parasit protozoa Plasmodium falciparum (Droucheau et al. 2004) dan Toxoplasma gondii (Qin et al. 1998). Pencirian GSK-3 parasit menunjukkan bahawa terdapat perbezaan antara GSK-3 parasit dan manusia yang mencadangkan bahawa pengawalaturan GSK-3 parasit adalah berlainan daripada GSK-3 manusia. Selain itu, perlakuan perencat GSK-3 dalam kajian infeksi in vitro Trypanosoma brucei (Ojo et al. 2008) dan Leishmania donovani (Xingi et al. 2009) didapati mengganggu perkembangan parasit. Oleh itu, GSK-3 mempunyai potensi sebagai sasaran dadah terhadap parasit protozoa.

Dalam kajian ini, jujukan pengekodan lengkap GSK-3 E. tenella telah dijana dan dicirikan. Maklumat daripada kajian ini diharapkan dapat mengenal pasti enzim GSK-3 sebagai calon baharu sasaran dadah antikoksidia yang wajar diperkembangkan.

\section{BAHAN DAN KAEDAH}

\section{PROPAGASI PARASIT DAN PENGESTRAKAN RNA JUMLAH}

Oosista E. tenella strain Houghton (H) telah dipropagasi dengan menggunakan ayam bebas koksidia sebagai perumah (Johan et al. 2011). Penuaian dan penulenan oosista dijalankan mengikut kaedah yang telah dilaporkan
(Soon et al. 2006). RNA jumlah telah diekstrak dengan larutan TRI Reagent ${ }^{\circledR}$ (Molecular Research Center Inc., USA). RNA jumlah telah ditulenkan dengan menggunakan kit RNeasy Mini (Qiagen, USA) mengikut protokol pengeluar. Kualiti dan kuantiti RNA jumlah ditentukan dengan menggunakan Spektrofotometer NanoDrop 2000 (Thermo Fisher Scientific, USA).

\section{AMPLIFIKASI DAN PENGKLONAN CDNA GSK-3}

Templat cDNA untuk amplifikasi hujung 5' dan 3' telah dihasilkan dengan menggunakan kit amplifikasi SMARTer ${ }^{\text {TM }}$ RACE CDNA (Clontech, Kanada) berdasarkan protokol pengeluar. Pencetus telah direka bentuk berdasarkan jujukan ramalan gen GSK-3 pada jujukan genom E. tenella (Reid et al.2014) yang telah diperoleh daripada pangkalan data GeneDB (www.genedb.org). Tindak balas amplifikasi telah dijalankan dengan menggunakan $\mathrm{MyTaq}^{\mathrm{TM}}$ DNA Polymerase (Bioline, USA) berdasarkan protokol pengeluar. Hasil PCR dipisahkan dengan elektroforesis gel agaros dan serpihan DNA yang dikehendaki dipotong, ditulen dan seterusnya diklonkan ke dalam vektor pGEM®-T (Promega, USA). Pemencilan plasmid daripada klon rekombinan dilakukan dengan menggunakan kit QIAprep ${ }^{\circledR}$ Spin Miniprep (Qiagen, USA) mengikut protokol pengeluar. Kehadiran selitan ditentukan dengan elektroforesis gel agaros dan penanda Supercoiled DNA Ladder, 2-10 kb (Promega, USA) digunakan untuk menganggar saiz selitan. Plasmid rekombinan yang mempunyai saiz selitan yang sesuai digunakan sebagai templat untuk penjujukan DNA dengan menggunakan kit ABI PRISM ${ }^{\circledR}$ BigDye $^{\mathrm{TM}}$ Terminator versi 3.1 Cycle Sequencing Ready Reaction (Applied Biosystems Inc. USA). Produk tindak balas penjujukan berkitar dianalisis dengan menggunakan mesin ABI PRISM 3730 Genetic Analyzer (Applied Biosystem Inc., USA).

\section{ANALISIS JUJUKAN}

Jujukan DNA yang terhasil dianalisis dengan menggunakan perisian Pregap4 versi 1.5 (Bonfield et al. 1996) untuk menyingkir jujukan vektor serta jujukan yang berkualiti rendah. Modul klip vektor telah digunakan untuk menyaring jujukan vektor pengklonan dan nilai Phred ditetapkan pada 30. Seterusnya, perhimpunan jujukan dilakukan dengan program CAP daripada perisian Bioedit (Hall 1999) untuk mendapatkan jujukan lengkap cDNA GSK-3 E.tenella. Perisian ORF Finder (www.ncbi.nlm.gov/ gorf) digunakan untuk meramal rangka bacaan terbuka (ORF). Hasil ramalan ORF yang paling panjang dipilih sebagai ORF bagi jujukan cDNA GSK-3 E. tenella. Jujukan pengekodan lengkap cDNA GSK-3 E. tenella digunakan untuk analisis pemadanan jujukan dengan menggunakan BLAST (Altschul et al. 1997). Penjajaran jujukan dilakukan untuk membandingkan jujukan putatif GSK-3 E. tenella dengan jujukan GSK-3 $\beta$ Homo sapiens (nombor capaian GenBank NP_002082.4) menggunakan perisian ClustalX v2.0 (Larkin et al. 2007). 
Penjajaran jujukan berbilang dilakukan dengan perisian Clustal Omega (Sievers et al. 2011) untuk membandingkan jujukan putatif asid amino GSK-3 E. tenella dengan jujukan asid amino GSK-3 lain. Perlombongan jujukan asid amino GSK-3 organisma lain dilakukan dengan menggunakan perisian DELTA-BLAST. Hanya jujukan asid amino yang lengkap sahaja dipilih untuk analisis penjajaran manakala jujukan separa yang pendek serta jujukan lewah disingkirkan. Parameter piawai yang ditetapkan dalam perisian digunakan untuk penjajaran. Perisian Bioedit pula digunakan untuk menyunting penjajaran secara manual. Perisian PHYLIP v3.2 (Felsenstein 1989) telah digunakan untuk analisis filogenetik. Perisian PROTDIST dan perisian PROTPARS dalam PHYLIP telah digunakan untuk menjana dua jenis pohon iaitu pohon sambungan jiran (NJ) dan parsimoni maksimum (MP). Kualiti dua pohon filogeni yang dibina telah dinilai dengan statistik butstrap sebanyak 1000 replikasi dengan menggunakan perisian SEQBOOT. Data replikasi tersebut kemudiannya digunakan dalam perisian CONSENSE untuk membina satu pohon konsensus daripada data yang diperoleh melalui analisis butstrap. Setiap cabang filogeni yang dijana oleh perisian CONSENSE mengandungi nilai aras keyakinan.

\section{PERAMALAN DAN ANALISIS STRUKTUR}

Peramalan struktur sekunder putatif GSK-3 E. tenella telah dilakukan dengan perisian PSIPRED (Jones 1999). Keputusan yang diperoleh telah dibandingkan dengan struktur sekunder GSK-3 T. gondii dan GSK-3 $\beta$ manusia. Pembinaan model homologi GSK-3 E. tenella pula telah dilakukan dengan perisian Swiss-Model (Biasini et al. 2014). Kualiti model protein telah dinilai setelah superposisi protein GSK-3 $\beta H$. sapiens dan struktur putatif E. tenella dilakukan dengan perisian UCSF Chimera (Pettersen et al. 2004). Algoritma penjajaran yang digunakan adalah Needleman-Wunsch dan matriks BLOSUM-62 merupakan matriks piawai. Skor penjajaran struktur sekunder bagi superposisi ditetapkan pada $30 \%$ dan kesemua penjajaran tidak melebihi 2.0 Å. Perisian Multialign Viewer pula telah digunakan untuk meneliti penjajaran jujukan antara dua protein tersebut bagi memilih residu yang penting untuk fungsi protein setelah analisis superposisi dilakukan.

\section{HASIL DAN PERBINCANGAN}

\section{ANALISIS JUJUKAN CDNA GSK-3 E. TENELLA}

Panjang jujukan cDNAGSK-3 E. tenella yang terjana adalah $1650 \mathrm{pb}$. Translasi jujukan dalam enam rangka bacaan menunjukkan bahawa ORF GSK-3 E. tenella terpanjang yang diramalkan adalah 1443 pb yang mengekod 480 asid amino. Kodon permulaan bagi jujukan ORF GSK-3 $E$. tenella yang diramalkan bermula daripada kodon ATG yang mengekod asid amino metionina pada bes 94 dan berakhir dengan kodon penamat TAG pada bes 1536 . Analisis BLASTx terhadap pangkalan data GenBank mendapati bahawa jujukan putatif GSK-3 E. tenella mempunyai pemadanan yang tinggi dengan jujukan asid amino GSK-3 organisma lain (Jadual 1). Julat peratus identiti bagi 10 pemadanan tertinggi berada dalam lingkungan 55-73\%. Antara 10 padanan yang terbaik, jujukan putatif GSK-3 E. tenella mempunyai pemadanan yang paling tinggi dengan homolog GSK-3 T. gondii dengan persamaan identiti sebanyak $73 \%$. Selain itu, jujukan putatif GSK3 E. tenella juga mempunyai pemadanan yang tinggi dengan jujukan GSK-3 Babesia bovis dan P. falciparum, masing-masing dengan persamaan identiti sebanyak 56 dan 55\%. Pemadanan yang tinggi dengan homolog GSK-3 parasit apikompleksa $T$. gondii, B. bovis dan P.falciparum mencadangkan bahawa jujukan ORF GSK-3 E. tenella merupakan jujukan pengekodan bagi homolog GSK-3 dalam E. tenella. Hasil analisis BLASTx juga mendapati bahawa jujukan putatif GSK-3 E. tenella mempunyai pemadanan yang tinggi dengan GSK-3 organisma alam Plantae. Daripada 10 pemadanan tertinggi, enam merupakan ahli daripada alam Plantae iaitu Physcomitrella patens, Marsilea vestita, Arabidopsis thaliana, Petunia $x$ hybrida, Triticum aestivum dan Chlamydomonas reinhardtii. Ini mencadangkan bahawa homolog GSK-3 $E$. tenella juga adalah rapat dengan homolog GSK-3 organisma alam Plantae.

Untuk mengenal pasti residu terpulihara, analisis penjajaran telah dilakukan dengan jujukan putatif GSK-3 E. tenella dan jujukan GSK-3 $\beta$ H. sapiens (Rajah 1). Hasil analisis menunjukkan bahawa kebanyakan residu yang penting untuk aktiviti GSK-3 $\beta$ adalah terpulihara dalam

JADUAL 1. Hasil analisis BLASTx bagi jujukan ORF GSK-3 E. tenella

\begin{tabular}{|c|c|c|c|c|}
\hline Organisma & $\begin{array}{l}\text { Panjang asid amino } \\
\text { (aa) }\end{array}$ & $\begin{array}{l}\text { Identiti } \\
(\%)\end{array}$ & $\begin{array}{l}\text { Nilai } \\
\text { E }\end{array}$ & $\begin{array}{c}\text { Nombor capaian } \\
\text { GenBank }\end{array}$ \\
\hline Toxoplasma gondii & 394 & 73 & $5 e-164$ & AAC27446.1 \\
\hline Marsilea vestita & 392 & 56 & $7 e-118$ & AFN42826.1 \\
\hline Arabidopsis thaliana & 410 & 56 & $5 e-117$ & AED92057.1 \\
\hline Triticum aestivum & 406 & 55 & $8 \mathrm{e}-116$ & BAF36565.1 \\
\hline Plasmodium falciparum & 440 & 55 & $9 \mathrm{e}-116$ & CAA15599.2 \\
\hline Oxytricha trifallax & 353 & 54 & $1 \mathrm{e}-115$ & EJY71817.1 \\
\hline Chlamydomonas reinhardtii & 387 & 55 & $6 e-115$ & AAT40314.1 \\
\hline
\end{tabular}




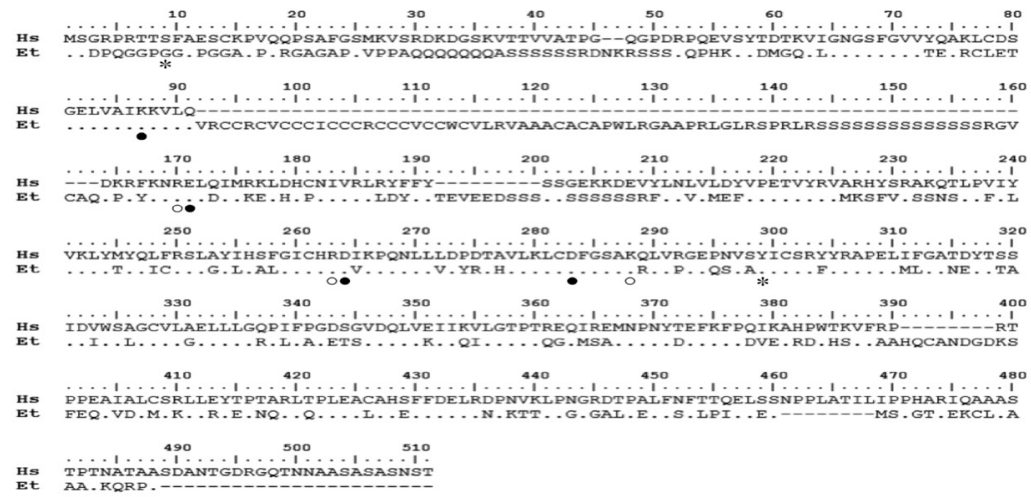

Tanda (.) dalam jujukan menandakan asid amino yang terpulihara. Ruang (-) terbentuk untuk mendapatkan penjajaran yang baik. Simbol bulatan hitam menandakan residu yang membentuk tapak pengikatan ATP, bulatan putih menandakan residu yang membentuk tapak pengikatan substrat GSK-3 dan asterisk menandakan residu serina dan tirosina yang penting untuk aktiviti GSK-3. (Hs) H. sapiens; (Et) E. tenella

RAJAH 1. Hasil analisis penjajaran antara jujukan GSK-3ß H. sapiens dan jujukan putatif GSK-3 E. tenella

jujukan putatif GSK-3 E. tenella. Tapak pengikatan ATP dalam GSK- $3 \beta$ H. sapiens yang terdiri daripada residu Lys 85, Glu 97, Asp 181 serta Asp 200 (ter Haar et al. 2001) adalah terpulihara dalam jujukan putatif GSK-3 E. tenella pada residu Lys 87, Glu 171, Asp 264 serta Asp 283. Selain itu, tapak pengikatan substrat GSK-3 iaitu residu Arg 96, Arg 180 dan Lys 205 bagi GSK-3 $\beta$ H. sapiens juga terpulihara dalam jujukan putatif GSK-3 E. tenella pada residu Arg 170, Arg 263 dan Lys 288. Pemuliharaan tapak pengikatan ATP dan tapak pengikatan substrat GSK$3 \beta$ dalam jujukan putatif GSK-3 E. tenella mencadangkan bahawa mekanisme pengaktifan kinase dan pengecaman substrat adalah serupa dengan GSK-3 $\beta$ H. sapiens.

Aktiviti GSK-3 $\beta H$. sapiens bergantung kepada pemfosfatan residu Ser 9 dan Tyr 216. Residu Ser 9 adalah penting untuk perencatan aktiviti enzim manakala residu Tyr 216 berfungsi untuk mengawal tahap aktiviti enzim (Cross et al. 1995). Residu Ser 9 tersebut didapati tidak terpulihara dalam jujukan putatif GSK-3 E. tenella dan ini mencadangkan bahawa mekanisme perencatan aktiviti GSK-3 E. tenella adalah berlainan. Pemuliharaan residu Tyr 216 GSK-3 $\beta$ pada residu Tyr 299 pula mencadangkan bahawa mekanisme pengawalan tahap aktiviti homolog GSK-3 E. tenella adalah serupa dengan GSK-3 $\beta$.

\section{ANALISIS PENJAJARAN JUJUKAN BERBILANG}

Jujukan putatif GSK-3 E. tenella telah dijajar dengan jujukan yang dilombong daripada pangkalan data GenBank (Rajah 2). Homolog GSK-3 Caenorhabditis elegans, Chlamydomonas reinhardtii, Daphnia pulex, Zea mays, Physcomitrella patens, Gallus gallus, H. sapiens, Mus musculus, T. gondii dan P. falciparum dipilih untuk mewakili pelbagai kumpulan organisma. Hasil analisis DELTA-BLAST menunjukkan bahawa jujukan putatif GSK-3 E. tenella dipadankan dengan isoform beta sahaja bagi jujukan GSK-3 haiwan vertebrata, maka jujukan GSK-3 $\beta$ bagi $H$. sapiens, $M$. musculus dan G. gallus digunakan dalam penjajaran ini. Hasil analisis penjajaran berbilang menunjukkan bahawa domain yang terlibat dengan pemangkinan protein kinase yang merupakan motif yang terpulihara dalam semua protein kinase serina/treonina (Hanks \& Quinn 1991), didapati hadir dalam semua jujukan yang dikaji. Tapak pengikatan ATP protein kinase yang mempunyai corak residu [LIV]-G$\{\mathrm{P}\}-\mathrm{G}-\{\mathrm{P}\}-[$ FYWMGSTNH]-[SGA]- $\{$ PW $\}$-[LIVCAT]- $\{\mathrm{PD}\}-$ $\mathrm{X}$-[GSTACLIVMFY]-X $(5,18)$-[LIVMFYWCSTAR]-[AIVP][LIVMFAGCKR]-K (nombor capaian PROSITE, PS00107) didapati terpulihara dalam semua jujukan daripada residu 101 sehingga residu 124. Beberapa penggantian yang diperhatikan melibatkan residu asid amino dengan ciri yang serupa. Misalnya, penggantian residu Ile $(C$. elegans, D. pulex, G. gallus, H. sapiens, M. musculus dan $P$. falciparum) ke Val (C. reinhardtii, Z. mays dan $P$. patens) dan Leu (T. gondii dan E. tenella) pada residu 101 melibatkan asid amino yang mempunyai rantai sisi bersifat hidrofobik. Oleh itu, penggantian ini diramalkan tidak mengubah sifat fizikal tapak pengikatan ATP.

Tapak aktif protein kinase serina/treonina yang mempunyai corak residu [LIVMFYC]-X-[HY]-X-D[LIVMFY]-K-x(2)-N-[LIVMFYCT] (nombor capaian PROSITE, PS00108) juga didapati terpulihara dalam semua jujukan daripada residu 299 sehingga residu 309. Namun begitu, penggantian Ile ke Leu diperhatikan bagi P.falciparum dan penggantian Ile ke Val diperhatikan bagi E. tenella pada residu 304. Penggantian ini diramalkan tidak mengubah sifat fizikal tapak pengikatan substrat oleh kerana keduaduanya mempunyai rantai sisi hidrofobik. Walaupun keterpuliharaan yang jelas diperhatikan dalam domain pemangkinan untuk semua jujukan, hujung $\mathrm{N}$ dan hujung $\mathrm{C}$ bagi homolog GSK-3 dalam penjajaran tidak menunjukkan keterpuliharaan yang jelas. Kajian pembandingan jujukan GSK-3 antara manusia dengan parasit (Osolodkin et al. 2011) serta tumbuhan (Jonak \& Hirt 2002) juga mendapati tiada keterpuliharaan yang jelas antara homolog GSK-3 pada hujung $\mathrm{N}$ dan hujung $\mathrm{C}$. 

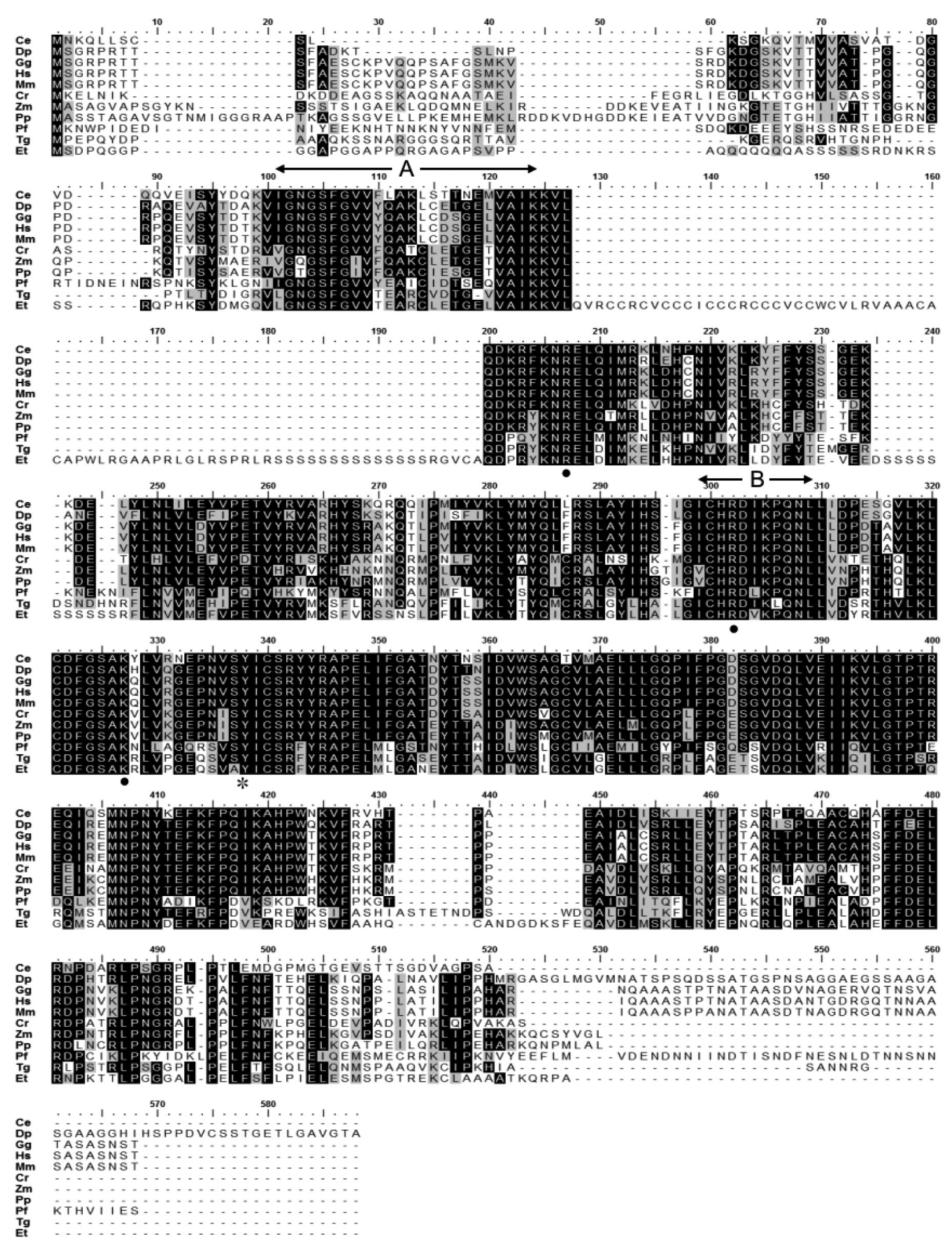

Kawasan berwarna kelabu merupakan residu yang serupa. Kawasan berwarna hitam merupakan residu yang terpulihara. Ruang (-) terbentuk untuk mendapatkan penjajaran yang terbaik. A dan B masing-masing menandakan corak residu terpulihara bagi tapak pengikatan ATP dan substrat bagi protein kinase. Simbol bulatan hitam menandakan residu yang penting dalam pengikatan substrat. Simbol asterisk menandakan residu tirosina yang penting untuk pengawalan tahap aktiviti GSK-3 $\beta$. (Ce) C. elegans; (Dp) D. pulex; (Gg) G. gallus; (Hs) H. sapiens; (Mm) M. musculus; (Cr) C. reinhardtii; (Zm) Z. mays; (Pp) P. patens; (Pf) P. falciparum; (Tg) T. gondii; (Et) E. tenella 
Hasil analisis penjajaran berbilang juga menunjukkan bahawa residu yang penting dalam pengikatan substrat GSK-3 $\beta$ iaitu residu 207, 302 dan 327 adalah terpulihara dalam semua jujukan. Ketiga-tiga residu ini memainkan peranan dalam pengikatan substrat yang telah melalui proses pemfosfatan terdahulu sebelum difosfatkan oleh GSK-3 (Frame \& Cohen 2001). Pemuliharaan residu ini mencadangkan bahawa mekanisme pengikatan substrat adalah sama bagi semua organisma dalam penjajaran. Selain itu, residu tirosina yang penting untuk pengawalan tahap aktiviti GSK-3 $\beta$ adalah terpulihara pada residu 338. Pemfosfatan residu tirosina (Tyr 216 bagi GSK-3 $\beta H$. sapiens) adalah penting sebagai pemangkin pengikatan substrat dan mengawal tahap aktiviti GSK-3 $\beta$ dalam sel (Wang et al. 1994). Pemuliharaan tapak residu tirosina dalam GSK-3 $\beta$ mencadangkan bahawa homolog GSK-3 organisma bukan vertebrata dalam penjajaran adalah lebih menyerupai GSK-3 $\beta$. Walau bagaimanapun, residu Ser 9 didapati tidak terpulihara antara organisma dalam penjajaran. Residu Ser 9 merupakan residu yang penting untuk perencatan aktiviti GSK-3 dalam haiwan vertebrata (Jope \& Johnson 2004). Perumah E. tenella, iaitu $G$. gallus mempunyai residu Ser 9 tetapi residu tersebut tidak terpulihara dalam jujukan putatif GSK-3 E. tenella. Pencirian homolog GSK-3 dalam T. gondii (Qin et al. 1998) dan P.falciparum (Droucheau et al. 2004) telah mendapati residu Ser 9 juga tidak terpulihara dalam parasit tersebut. Ini mencadangkan bahawa mekanisme perencatan GSK-3 parasit apikompleksa mungkin berlainan dengan perumah parasit. Hasil analisis penjajaran berbilang juga telah menunjukkan satu ciri yang unik bagi jujukan putatif GSK-3 E. tenella, iaitu jujukan peptida sepanjang 71 asid amino yang hanya wujud pada jujukan putatif GSK-3 E. tenella daripada residu 128 sehingga residu 199. Perbandingan lanjut dengan jujukan homolog GSK-3 organisma lain daripada pangkalan data GenBank mendapati bahawa jujukan peptida ini adalah spesifik terhadap E. tenella sahaja.

\section{ANALISIS FILOGENETIK}

Jujukan GSK-3 yang telah digunakan untuk analisis penjajaran jujukan berbilang bagi pembinaan pohon $\mathrm{NJ}$ dan MP telah dipilih daripada jujukan lengkap GSK-3 yang dilombong daripada analisis DELTA-BLAST serta pangkalan data GenBank. Sebanyak 16 jujukan GSK-3 telah dipilih daripada spesies yang merangkumi alam Haiwan, Plantae, Amoebozoa serta parasit apikompleksa. Untuk analisis filogenetik, hanya jujukan yang merangkumi domain terpulihara serta tapak penting bagi fungsi protein telah digunakan dalam penjajaran jujukan berbilang. Kajian awal telah menunjukkan bahawa penumpuan terhadap domain terpulihara dalam analisis filogenetik boleh meningkatkan isyarat filogenetik untuk menghasilkan pohon filogeni yang lebih baik terutamanya bagi jujukan asid amino (Azizan et al. 2014; Lee et al. 2012; Talavera \& Castresana 2007).

Pohon NJ dan MP yang telah diakarkan dengan jujukan asid amino Dictyostelium discoideum dan Polysphondylium pallidum menunjukkan semua jujukan GSK-3 organisma yang dikaji adalah monofiletik dan disokong dengan aras keyakinan $100 \%$ (Rajah 3). Dua klad telah diperhatikan dalam dua pohon tersebut iaitu klad I yang terdiri daripada organisma alam Haiwan dan klad II yang terdiri daripada parasit apikompleksa dan organisma alam Plantae. Dalam kumpulan parasit apikompleksa di klad II, jujukan GSK-3 E. tenella didapati berkait rapat dengan $T$. gondii. Daripada segi taksonomi, dua organisma ini dikelaskan di bawah Order Eucoccidiorida. Pertalian yang rapat ini juga telah dilaporkan dalam kajian filogenetik awal yang telah dijalankan untuk protein E. tenella seperti piruvat kinase (Labbé et al. 2006) dan glukosa-6-fosfat isomerase (Loo et al. 2010). Selain itu, pertalian rapat yang diperhatikan antara jujukan GSK-3 P. falciparum dan P. yoelii (order Haemosporida) dengan $B$. bovis dan $T$. orientalis (order Piroplasmida) menyokong hasil kajian filogenetik awal yang mencadangkan bahawa organisma daripada dua order tersebut berdekatan daripada segi evolusi (Kuo et al. 2008).

Hasil analisis filogenetik juga mencadangkan bahawa jujukan GSK-3 parasit apikompleksa mempunyai pertalian yang rapat dengan kumpulan plantae yang diwakili oleh A. thaliana, M. sativa, T. aestivum dan Z. mays. Topologi ini menyokong hasil kajian awal analisis filogenetik rRNA subunit kecil yang mencadangkan bahawa parasit apikompleksa mempunyai pertalian yang rapat dengan organisma alam Plantae (Van de Peer et al. 2000). Pertalian yang rapat ini dipercayai berkaitan dengan kehadiran organel plastid dalam parasit apikompleksa yang telah diperoleh secara endosimbiosis daripada alga hijau (Kohler et al. 1997; Lau et al. 2009) atau pun alga merah (Janouškovec et al. 2010). Secara keseluruhannya, hasil analisis filogenetik mencadangkan bahawa GSK-3 E. tenella merupakan sasaran dadah antikoksidia yang berpotensi. Pengelompokan jujukan putatif GSK-3 E. tenella dalam klad yang berbeza daripada perumahnya iaitu G. gallus mungkin membolehkan reka bentuk perencat spesifik untuk bertindak terhadap aktiviti GSK-3 E. tenella sahaja tanpa mempengaruhi aktiviti enzim GSK-3 perumahnya.

\section{ANALISIS STRUKTUR PROTEIN PUTATIF GSK-3 E. TENELLA}

Hasil analisis PSIPRED meramalkan bahawa struktur sekunder putatif GSK-3 E. tenella yang terdiri daripada 480 residu mempunyai 12 heliks alfa dan 12 bebenang beta. Perbandingan telah dilakukan antara struktur sekunder putatif GSK-3 E. tenella dan struktur sekunder putatif GSK-3 T. gondii yang juga merupakan ramalan PSIPRED berdasarkan jujukan ORF GSK-3 T. gondii (Qin et al. 1998) serta struktur sekunder GSK-3 $\beta$ H. sapiens (nombor capaian UniProt P49841) yang dihasilkan berdasarkan struktur 3D GSK-3 $\beta$ H. sapiens (Dajani et al. 2003) (Rajah 4). Analisis perbandingan struktur sekunder ini menunjukkan bahawa terdapatnya pembahagian domain yang ketara bagi ketiga-tiga struktur protein tersebut. Domain hujung $\mathrm{N}$ mempunyai lebih banyak bebenang beta manakala domain hujung $\mathrm{C}$ mempunyai lebih banyak heliks alfa. Pembahagian domain yang ketara ini merupakan ciri 


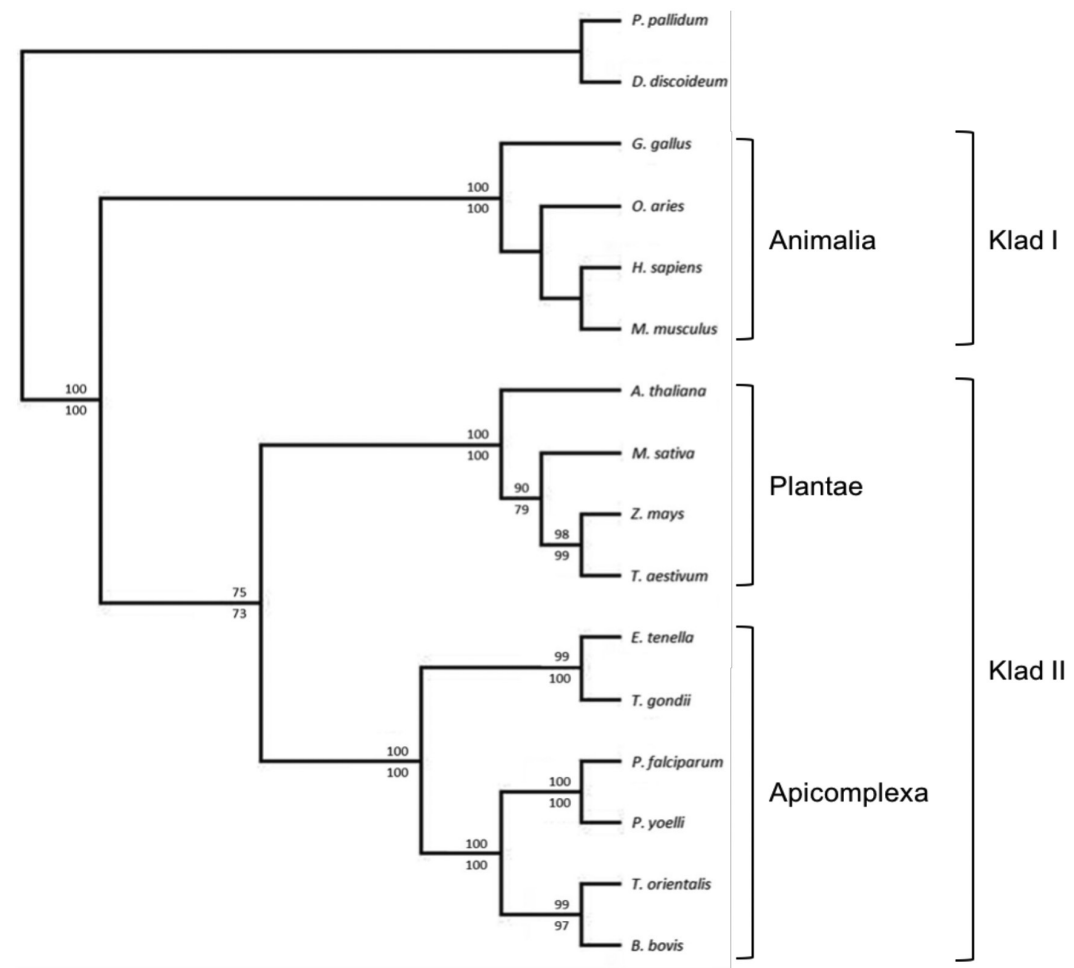

Nilai di atas cabang mewakili aras keyakinan bagi pohon filogeni NJ sebanyak 1000 ulangan manakala nilai di bawah cabang mewakili aras keyakinan pohon filogeni MP sebanyak 1000 ulangan. Jujukan yang digunakan dalam analisis adalah Arabidopsis thaliana (nombor capaian GenBank NP_196968.2), Babesia bovis (BAN65470.1), Dictyostelium discoideum (XP 645156.1), Gallus gallus (XP 416557.4), Homo sapiens (NP_001139628.1), Medicago sativa (AAN63591.1), Mus musculus (NP_062801.1), Ovis aries (NP_001123212.1), Plasmodium falciparum (CAA15599.2), Plasmodium yoelli (CDU16507.1), Polysphondylium pallidum (EFA84486.1), Theileria orientalis (BAM41559.1), Toxoplasma gondii (AAC27446.1), Triticus aestivum (BAF36565.1) dan Zea mays (NP_001148880.1)

RAJAH 3. Pohon filogeni NJ dan MP yang dijana daripada jujukan putatif GSK-3 E. tenella
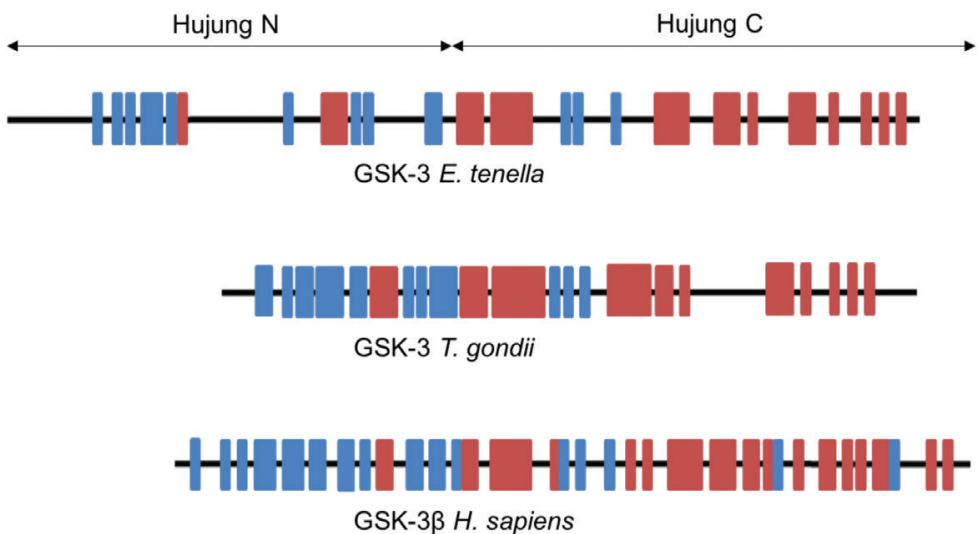

Petak berwarna biru mewakili bebenang beta dan petak berwarna merah mewakili heliks alfa

RAJAH 4. Perbandingan struktur sekunder putatif GSK-3 E. tenella, GSK-3 T. gondii dan GSK-3 $\beta$ H. sapiens

terpulihara bagi protein kinase (Hanks \& Quinn 1991; ter Haar et al. 2001; Xiao et al. 2004).

Model protein GSK-3 E. tenella telah dibina dengan menggunakan acuan struktur 3D GSK-3 $\beta$ manusia (kod PDB 4nm0). Jujukan asid amino residu 54 sehingga 470 telah digunakan dalam pembinaan model ini. Pembandingan model GSK-3 E. tenella yang terhasil terhadap GSK-3 $\beta$
H. sapiens mendapati perbezaan RMS sebanyak $0.67 \AA$. Hasil pembinaan model GSK-3 E. tenella menyokong hasil analisis awal yang mencadangkan bahawa terdapatnya pembahagian domain yang ketara dalam protein ini (Rajah 5). Model GSK-3 E. tenella terbahagi kepada domain hujung $\mathrm{N}$ yang mempunyai lebih banyak bebenang beta manakala domain hujung $\mathrm{C}$ pula mempunyai lebih banyak 


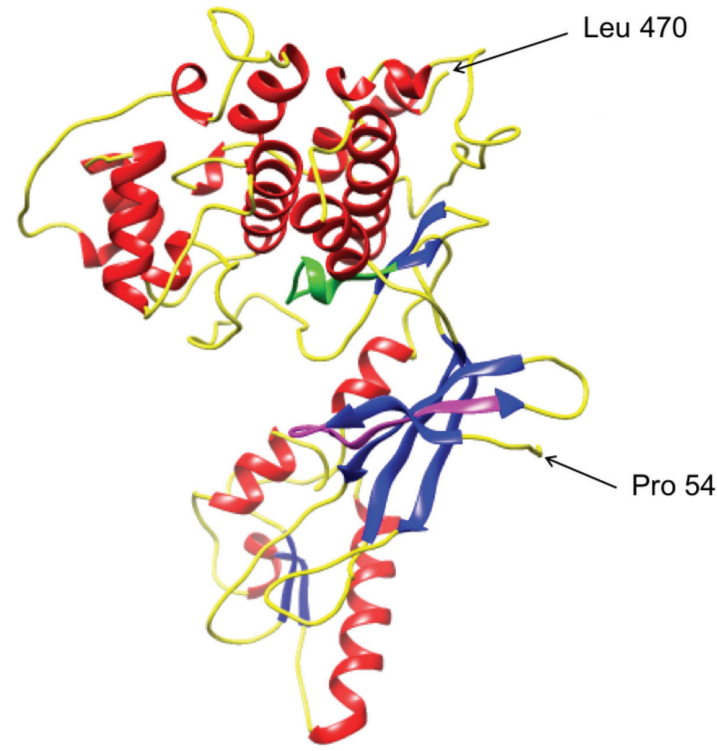

Warna merah mewakili heliks alfa dan warna biru mewakili bebenang beta. Warna hijau mewakili tapak aktif protein dan warna ungu mewakili tapak pengikatan ATP protein

RAJAH 5. Struktur sekunder GSK-3 E. tenella daripada hujung N pada residu Pro 54 sehingga hujung C pada residu Leu 470

heliks alfa. Domain hujung $\mathrm{N}$ antara bebenang beta ke-6 dan ke-7 diganggu oleh heliks alfa. Terdapat dua residu pada heliks alfa tersebut iaitu Arg 170 dan Glu 171 yang diramal memainkan peranan penting dalam fungsi protein. Dalam GSK-3 H. sapiens, residu Arg 96 terlibat dalam penjajaran domain protein manakala residu Glu 97 pula membentuk ikatan hidrogen dengan Lys 85 yang merupakan residu penting dalam aktiviti pemangkinan protein (Meijer et al. 2003).

Pertindihan struktur protein menyokong hasil analisis awal yang mencadangkan bahawa residu yang penting untuk fungsi protein GSK-3 adalah terpulihara dalam GSK-3 E. tenella (Rajah 6). Arg 170, Arg 263 dan Lys 288 diramalkan bertindak terhadap kumpulan fosfat dalam substrat manakala Tyr 299, residu yang mengawal tahap aktiviti GSK-3 E. tenella, bertindak sebagai pagar kepada tapak pengikatan substrat. Perbandingan dengan tapak pengikatan substrat GSK-3 $\beta$ manusia menunjukkan bahawa tulang belakang serta rantai sisi bagi residu yang penting adalah terpulihara dalam GSK-3 E. tenella. Ini menyokong cadangan bahawa mekanisme pengecaman substrat dan pengawalan aktiviti GSK-3 E. tenella adalah sama dengan GSK-3 $\beta$ H. sapiens.

Selain itu, perbandingan model GSK-3 E. tenella juga dilakukan dengan protein GSK-3 $\beta H$. sapiens yang mengikat kepada perencat 6-bromoindirubin-3'-oxime (BIO) (kod PDB 1uv5) untuk meneliti interaksi GSK-3 E. tenella dengan perencat tersebut (Rajah 7). Perencat BIO bertindak merencat GSK-3 melalui persaingan dengan ATP di tapak pengikatan (Meijer et al. 2003). Selain daripada interaksi dengan residu Lys 85, Glu 97, His 155 dan Asp 200, pengikatan BIO di tapak pengikatan ATP GSK-3 $H$. sapiens berlaku melalui tiga pengikatan hidrogen pada residu Val 135 dan Asp 133 GSK-3 $\beta$ H. sapiens. Walaupun Lys 85, Glu 97, His 155, Asp 200 dan Val 135 adalah terpulihara di dalam GSK-3 E. tenella pada residu Lys 87, Glu 171, His 264 dan Val 218, residu Asp 133 didapati tidak terpulihara dalam GSK-3 E. tenella dan diganti oleh residu Glu 216. Walau bagaimanapun, penggantian residu ini diramalkan tidak mengubah tapak pengikatan ATP GSK-3 E. tenella oleh kerana kedua-dua residu Asp dan Glu mempunyai rantai sisi yang bercaj negatif dan bersaiz setara. Hasil analisis pembandingan model menunjukkan bahawa tiga pengikatan hidrogen diramalkan berlaku antara perencat BIO dan residu Val 218 serta Glu 216 GSK3 E. tenella. Kesemua pengikatan hidrogen diramalkan berlaku pada tulang belakang peptida dan tidak melibatkan sebarang rantai sisi protein. Ini mencadangkan bahawa perencat BIO berupaya merencat GSK-3 E. tenella dalam mekanisme yang serupa seperti GSK-3 $\beta H$. sapiens.

\section{KESIMPULAN}

Secara keseluruhannya, keputusan kajian ini telah menunjukkan bahawa jujukan cDNA yang terjana mengekodkan GSK-3 E. tenella dan molekul ini mempunyai potensi sebagai sasaran dadah antikoksidia serta wajar

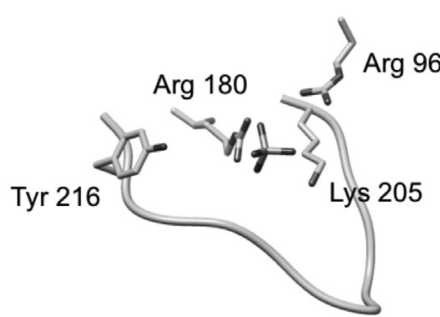

(a)

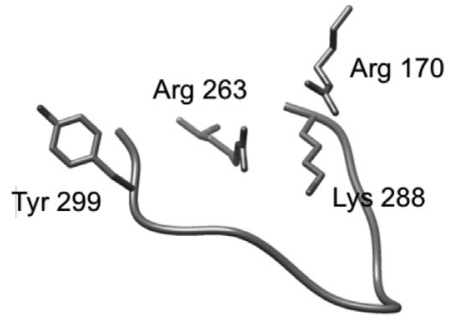

(b)

RAJAH 6. Perbandingan tapak pengikatan substrat antara (a) GSK-3 $\beta$ H. sapiens yang ditambat ion fosfat dan (b) GSK-3 E. tenella 


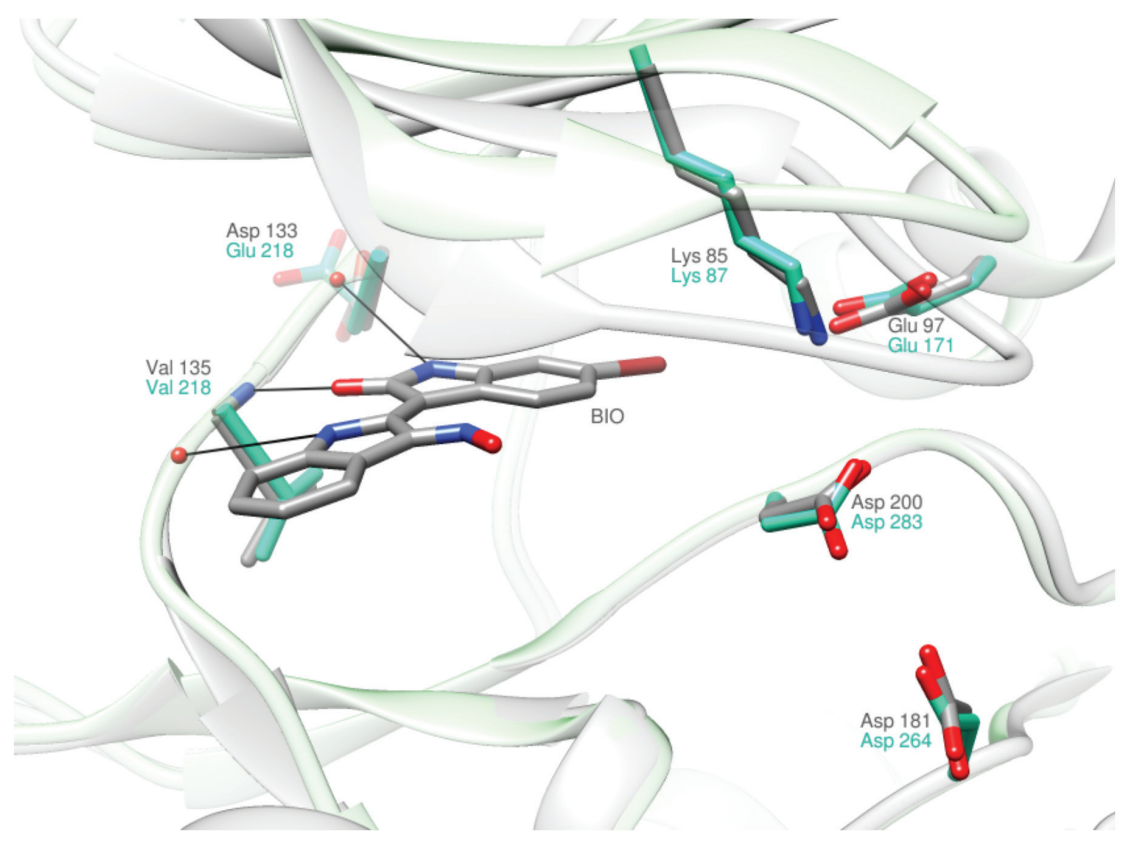

Residu GSK-3 $\beta$ H. sapiens serta perencat BIO diwarnakan kelabu manakala residu GSK-3 E. tenella diwarnakan sian. Ion hidrogen diwarnakan merah dan ion amonium diwarnakan biru

RAJAH 7. Superposisi GSK-3 $\beta$ H. sapiens dan GSK-3 E. tenella pada tapak pengikatan perencat BIO

diperkembangkan. Namun begitu, kajian ini hanya merupakan langkah awal untuk mengkaji kesesuaian GSK-3 E. tenella sebagai calon sasaran dadah antikoksidia yang baharu. Kajian lanjutan seperti pengasaian aktiviti enzim dan pengenalpastian substrat GSK-3 akan memberi maklumat lanjut tentang peranan yang dimainkan oleh protein GSK-3 dalam E. tenella. Diharapkan maklumat daripada kajian ini dapat dimanfaatkan dalam usaha seterusnya untuk memperkembangkan GSK-3 E. tenella sebagai sasaran dadah antikoksidia yang baharu.

\section{PENGHARGAAN}

Penyelidikan ini telah dibiayai melalui peruntukan Institut Farmaseutikal dan Nutraseutikal, Kementerian Sains, Teknologi dan Inovasi, Malaysia (09-05-IFN-BPH-001) dan Dana Universiti Penyelidikan UKM (DIP-2012-21).

\section{RUJUKAN}

Ali, A., Hoeflich, K.P. \& Woodgett, J.R. 2001. Glycogen synthase kinase-3: Properties, functions and regulations. Chemical Reviews 101: 2527-2540.

Allen, P.C. \& Fetterer, R.H. 2002. Recent advances in biology and immunobiology of Eimeria species and in diagnosis and control of infection with these coccidian parasites of poultry. Clinical Microbiology Reviews 15(1): 58-65.

Altschul, S.F., Madden, T.L., Schaffer, A.A., Zhang, J., Zhang, Z., Miller, W. \& Lipman, D.J. 1997. Gapped BLAST and PSI-BLAST: A new generation of protein database search programs. Nucleic Acids Research 25(17): 3389-3402.

Azizan, S., Wan, K.L. \& Mohd-Adnan, A. 2014. Molecular characterisation and expression analysis of cathepsin D from the Asian seabass Lates calcarifer. Sains Malaysiana 43(8): 1139-1148.
Biasini, M., Bienert, S., Waterhouse, A., Arnold, K., Studer, G., Schmidt, T., Kiefer, F., Cassarino, T.G., Bertoni, M., Bordoli, L. \& Schwede T. 2014. Swiss-Model: Modelling protein tertiary and quaternary structure usinge evolutionary information. Nucleic Acids Research 42(Web Server issue): 252-258.

Blake, D.P. \& Tomley, F.M. 2014. Securing poultry production from the ever-present Eimeria challenge. Trends in Parasitology 30: 12-19.

Bonfield, J.K., Smith, K.F. \& Staden, R. 1996. A new DNA sequence assembly program. Nucleic Acids Research 23: 4992-4999.

Chapman, H.D. 1997. Biochemical, genetic and applied aspects of drug resistance in Eimeria parasites of the fowl. Avian Pathology 26(2): 221-244.

Chapman, H.D., Jeffers, T.K. \& Williams, R.B. 2010. Forty years of monensin for the control of coccidiosis in poultry. Poultry Science 89(9): 1788-1801.

Cross, D.A., Alessi, D.R., Cohen, P., Andjelkovich, M. \& Hemmings, B.A. 1995. Inhibition of glycogen synthase kinase- 3 by insulin mediated by protein kinase B. Nature 378(6559): 785-789.

Dajani, R., Fraser, E., Roe, S.M., Yeo, M., Good, V.M., Thompson, V., Dale, T.C. \& Pearl, L.H. 2003. Structural basis for recruitment of glycogen synthase kinase 3 beta to the axin-APC scaffold complex. EMBO Journal 22(3): 494501.

Droucheau, E., Primot, A., Thomas, V., Mattei, D., Knockaert, M., Richardson, C., Sallicandro, P., Alano, P., Jafarshad, A., Baratte, B., Kunick, C., Parzy, D., Pearl, L., Doerig, C. \& Meijer, L. 2004. Plasmodium falciparum glycogen synthase kinase-3: molecular model, expression, intracellular localisation and selective inhibitors. Biochimica et Biophysica Acta 1697(1-2): 181-196.

Embi, N., Rylatt, D.B. \& Cohen, P. 1980. Glycogen synthase kinase-3 from rabbit skeletal muscle-separation from 
cyclic-AMP-dependent protein kinase and phosphorylase kinase. European Journal of Biochemistry 107(2): 519-527.

Felsenstein, J. 1989. PHYLIP - Phylogeny Inference Package (Version 3.2). Cladistics 5: 164-166.

Frame, S. \& Cohen, P. 2001. GSK3 takes centre stage more than 20 years after its discovery. Biochemical Journal 359: 1-16.

Hall, T.A. 1999. BioEdit: A user-friendly biological sequence alignment editor and analysis program for Windows 95/98/ NT. Nucleic Acids Symposium Series 41: 95-98.

Hanks, S.K. \& Quinn, A.M. 1991. Protein kinase catalytic domain sequence database: Identification of conserved features of primary structure and classification of family members. Methods in Enzymology 200: 38-62.

Janouškovec, J., Horák, A., Oborník, M., Lukeš, J. \& Keeling, P.J. 2010. A common red algal origin of the apicomplexan, dinoflagellate and heterokont plastids. Proceedings of the National Academy of Sciences U.S.A. 107(24): 1094910954.

Johan, N., Jangi, M.S. \& Wan, K.L. 2011. Pemencilan dan pencirian populasi Eimeria tenella daripada ayam hutan tempatan. Sains Malaysiana 38(6): 939-945.

Jonak, C. \& Hirt, H. 2002. Glycogen synthase kinase 3/ SHAGGY-like kinases in plants: An emerging family with novel functions. Trends in Plant Science 7(10): 457-461.

Jones, D.T. 1999. Protein secondary structure prediction based on position-specific scoring matrices. Journal of Molecular Biology 292(2): 195-202.

Jope, R.S. \& Johnson, G.V. 2004. The glamour and gloom of glycogen synthase kinase-3. Trends in Biochemical Sciences 29(2): 95-102.

Kohler, S., Delwiche, C.F., Denny, P.W., Tilney, L.G., Webster, P., Wilson, R.J., Palmer, J.D. \& Roos, D.S. 1997. A plastid of probable green algal origin in Apicomplexan parasites. Science 275(5305): 1485-1489.

Kuo, C.H., Wares, J.P. \& Kissinger, J.C. 2008. The Apicomplexan-whole genome phylogeny: an analysis of incongruence among gene trees. Molecular Biology and Evolution 25(12): 2689-2698.

Labbé, M., Péroval, M., Bourdieu, C., Girard-Misguich, F. \& Péry, P. 2006. Eimeria tenella enolase and pyruvate kinase: A likely role in glycolysis and in others functions. International Journal for Parasitology 36(14): 1443-1452.

Larkin, M.A., Blackshields, G., Brown, N.P., Chenna, R., McGettigan, P.A., McWilliam, H., Valentin, F., Wallace, I.M., Wilm, A., Lopez, R., Thompson, J.D., Gibson, T.J. \& Higgins, D.G. 2007. Clustal W and Clustal X version 2.0. Bioinformatics 23(21): 2947-2948.

Lau, A.O.T., McElwain, T.F., Brayton, K.A., Knowles, D.P. \& Roalson, E.H. 2009. Babesia bovis: A comprehensive phylogenetic analysis of plastid-encoded genes supports green algal origin of apicoplasts. Experimental Parasitology 123(3): 236-243.

Lee, J.H., Wan, K.L., Mohd-Adnan, A. \& Gabaldón, T. 2012. Evolution of the ferritin family in vertebrates. Trends in Evolutionary Biology 4: e3.

Loo, S.S., Blake, D.P., Mohd-Adnan, A., Mohamed, R. \& Wan, K.L. 2010. Eimeria tenella glucose-6-phosphate isomerase: Molecular characterization and assessment as a target for anti-coccidial control. Parasitology 137: 1169-1177.

Meijer, L., Skaltsounis, A.L., Magiatis, P., Polychronopoulos, P., Knockaert, M., Leost, M., Ryan, X.P., Vonica, C.A., Brivanlou, A., Dajani, R., Crovace, C., Tarricone, C., Musacchio, A., Roe, S.M., Pearl, L. \& Greengard, P. 2003.
GSK-3 selective inhibitors derived from Tyrian Purple Indirubins. Chemistry \& Biology 10(12): 1255-1266.

Ojo, K.K., Gillespie, J.R., Riechers, A.J., Napuli, A.J., Verlinde, C.L., Buckner, F.S., Gelb, M.H., Domostoj, M.M., Wells, S.J., Scheer, A., Wells, T.N. \& Van Voorhis, W.C. 2008. Glycogen synthase kinase 3 is a potential drug target for African trypanosomiasis therapy. Antimicrobial Agents and Chemotherapy 52(10): 3710-3717.

Osolodkin, D.I., Zakharevich, N.V., Palyulin, V.A., Danilenko, V.N. \& Zefirov, N.S. 2011. Bioinformatic analysis of glycogen synthase kinase 3: Human versus parasite kinases. Parasitology 138(6): 725-735.

Pettersen, E.F., Goddard, T.D., Huang, C.C., Couch, G.S., Greenblatt, D.M., Meng, E.C. \& Ferrin, T.E. 2004. UCSF Chimera: A visualization system for exploratory research and analysis. Journal of Computational Chemistry 25(13): 1605-1612.

Qin, C.L., Tang, J. \& Kim, K. 1998. Cloning and in vitro expression of TPK3, a Toxoplasma gondii homologue of shaggy/glycogen synthase kinase-3 kinases. Molecular and Biochemical Parasitology 93(2): 273-283.

Reid, A.J., Blake, D.P., Ansari, H.R., Billington, K., Browne, H.P., Bryant, J., Dunn, M., Hung, S.S., Kawahara, F., MirandaSaavedra, D., Malas, T.B., Mourier, T., Naghra, H., Nair, M., Otto, T.D., Rawlings, N.D., Rivailler, P., Sanchez-Flores, A., Sanders, M., Subramaniam, C., Tay, Y.L., Woo, Y., Wu, X., Barrell, B., Dear, P.H., Doerig, C., Gruber, A., Ivens, A.C., Parkinson, J., Rajandream, M.A., Shirley, M.W., Wan, K.L., Berriman, M., Tomley, F.M. \& Pain, A. 2014. Genomic analysis of the causative agents of coccidiosis in domestic chickens. Genome Research 24: 1676-1685.

Shirley, M.W., Smith, A.L. \& Tomley, F.M. 2005. The biology of avian Eimeria with an emphasis on their control by vaccination. Advances in Parasitology 60: 285-330.

Sievers, F., Wilm, A., Dineen, D., Gibson, T.J., Karplus, K., Li, W., Lopez, R., McWilliam, H., Remmert, M., Soding, J., Thompson, J.D. \& Higgins, D.G. 2011. Fast, scalable generation of high-quality protein multiple sequence alignments using Clustal Omega. Molecular System Biology 7: 539.

Soon, P.E., Tomley, F.M., Jangi, M.S. \& Wan, K.L. 2006. Pengenalpastian protein membran putatif dalam sporozoit Eimeria tenella melalui penyaringan imuno. Sains Malaysiana 35(2): 23-28.

Talavera, G. \& Castresana, J. 2007. Improvement of phylogenies after removing divergent and ambiguously aligned blocks from protein sequence alignments. Systematic Biology 56: 564-577.

ter Haar, E., Coll, J.T., Austen, D.A., Hsiao, H.M., Swenson, L. \& Jain, J. 2001. Structure of GSK3 beta reveals a primed phosphorylation mechanism. Nature Structural Biology 8(7): 593-596.

Van de Peer, Y., Baldauf, S.L., Doolittle, W.F. \& Meyer, A. 2000. An updated and comprehensive rRNA phylogeny of (crown) eukaryotes based on rate-calibrated evolutionary distances. Journal of Molecular Evolution 51(2000): 565-576.

Wang, Q.M., Fiol, C.J., DePaoli-Roach, A.A. \& Roach, P.J. 1994. Glycogen synthase kinase-3 beta is a dual specificity kinase differentially regulated by tyrosine and serine/threonine phosphorylation. Journal of Biological Chemistry 269(20): 14566-14574.

Williams, R.B. 2002. Fifty years of anticoccidial vaccines for poultry (1952-2002). Avian Diseases 46(4): 775-802. 
Xiao, J.F., Li, Z.S., Sun, M., Zhang, Y. \& Sun, C.C. 2004. Homology modeling and molecular dynamics study of GSK3/ SHAGGY-like kinase. Computational Biology and Chemistry 28(3): 179-188.

Xingi, E., Smirlis, D., Myrianthopoulos, V., Magiatis, P., Grant, K.M., Meijer, L., Mikros, E., Skaltsounis, A.L. \& Soteriadou, K. 2009. 6-Br-5methylindirubin-3'oxime (5-Me-6-BIO) targeting the leishmanial glycogen synthase kinase-3 (GSK3) short form affects cell-cycle progression and induces apoptosis-like death: Exploitation of GSK-3 for treating leishmaniasis. International Journal for Parasitology 39(12): 1289-1303.
Pusat Pengajian Biosains \& Bioteknologi

Fakulti Sains dan Teknologi

Universiti Kebangsaan Malaysia

43600 Bangi, Selangor Darul Ehsan

Malaysia

*Pengarang untuk surat-menyurat; email: klwan@ukm.edu.my

Diserahkan: 14 April 2016

Diterima: 26 Oktober 2016 